\title{
Wrémada: Sebuah Transformasi Tantri dalam Pertunjukan Wayang Bali
}

\author{
I Kadek Bhaswara Dwitiya \\ Pengkajian Seni, Pasca Sarjana Institut Seni Indonesia Yogyakarta \\ Email: bhaswaradwitiya@yahoo.com
}

\begin{abstract}
"Wrémada" is reinterpretations of once episode of Tantri stories, it's to respond of social-culture phenomena in Indonesia. As we know, the television programs expose coruption in some departmens and institutions. In the other side, the majority of Indonesia society wereunderestimating of traditional arts. Based on this phenomena, title of this art work was used "Wrémada", it's mean is "the monkey was stunned by position and authorities. This art work to fuse three genre, there are wayang golek, wayang peteng, dan wayang lemah, in which each of those had different of playing technical and space. But they were colaborated to be one unity art work, and so, this art work can be accepted of Baliness society. And it explained once widya component of Tantri's story, so it be rebornd and reflected by Indonesia society, and so to build a nations character based on local norm and convention. My expectations of tenants, it can be wise and be guided by the chess pariksa or called by the name of chess nayasandhi is the same, different, funds, and danda.
\end{abstract}

Keywords: Tantri; interpretation; creativity; widya; human character

\begin{abstract}
Abstrak
"Wrémada" merupakan reinterpretasi dari salah satu cerita dalam Tantri, untuk merespon kondisi sosial budaya bangsa Indonesia dewasa ini. Sebagaimana banyak diberitakan di televisi tentang pejabat tinggi negara yang terjerat kasus korupsi. Fakta demikian ditunjang oleh kondisi budaya bangsa khususnya kesenian tradisional yang menunjukkan adanya gejala mulai terpinggirkan. Atas dasar hal tersebut maka karya ini diberi judul "Wremada", yang artinya kera yang mabuk jabatan dan kekuasaan. Karya ini merupakan gabungan tiga jenis wayang, yaitu wayang golek, wayang peteng, dan wayang lemah. Ketiganya memiliki teknik bermain dan ruang gerak yang berbeda, kemudian dikolaborasikan menjadi satu kesatuan karya yang utuh. Karya ini dimaksudkan untuk menjabarkan salah satu komponen widya dalam cerita Tantri agar dikenali kembali oleh masyarakat. Karya ini juga diharapkan dapat bermanfaat dalam pembangunan karakter bangsa, khususnya pola perilaku yang sesuai dengan nilai-nilai bangsa sesuai dengan kapasitas masing-masing. Harapan penggarap, karya ini dapat dijadikan cermin bagi masyarakat agar bersikap bijaksana dengan berpedoman pada catur pariksa atau catur nayasandhi,yang meliputi sama, beda, dana, dan danda.
\end{abstract}

Kata kunci: Tantri; interpretasi; karya; widya; karakter manusia 


\section{Pendahuluan}

Meski era reformasi telah berjalan hampir dua dekade, namun pada kenyataannya belum mampu menunjukkan arah kehidupan bernegara dan berbangsa sebagaimana yang diidam-idamkan oleh seluruh bangsa. Hampir setiap hari, stasiun televisi selalu menyiarkan persoalan korupsi yang sedemikian luar biasa yang dilakukan oleh pejabat tinggi negarayangsangat terhormat. Berbagai konflik kepentingan politik selalu mewarnai pemberitaan media massa. Berbagai kesulitan hidup rakyat jelata masih banyak mewarnai realitas sosial bangsa ini. Perilaku peradialan masih banyak menuai kritik, bahkan dari para insan hukum sendiri. Meskipun banyak elit politik yang mengklaim bahwa mereka telah berjuang keras dan memikirkan rakyat dan negara hingga berdarah-darah, toh kenyataannya, rakyat kecil belum bisa merasakan dampaknya, bahkan kebutuhan hidup semakin merangkak naik, jauh meninggalkan tingkat penghasilannya. Hal demikian menunjukkan bahwa masih banyak lagi persoalan berbangsa dan bernegara yang perlu diperbaiki.

Sebagai insan pedalangan yang relatif dekat dengan masyarakat bawah, realitas tersebut mendorong saya untuk berkarya dengan mengangkat salah satu cerita dalam Tantri, yang relevan dengan persoalan di atas, yaitu kisah seekor kera yang lalai atas kewajibannya ketika mendapat amanah untuk menjadi pemimpin. Dipilihnya topik ini untuk menunjukkan bahwa dalam masyarakat kita banyak bertebaran berbagai pengetahuan hidup yang dibungkus dalam bentuk cerita rakyat, yang perlu digali untuk dikembangkan dan dipopulerkan kembali dalam kehidupan masyarakat kita. Hal ini penting karena pada kenyataannya, cerita-cerita tersebut sudah mulai ditinggalkan masyarakat, khususnya generasi muda karena dianggap kuna. Tentunya, tujuan di atas tidak akan tercapai apabila tidak dilakukan penafsiran ulang untuk disesuaikan dengan situasi dan kondisi masyarakat sekarang.

Mengikuti pandangan Wahyudi (periksa Wayang Nusantara, Vol.1 No.1 2014: 10) yang menyatakan bahwa rootmap logika dalam karya adalah kebalikan dari pengkajian, yakni berangkat dari gagasan yang kemudian diaktualisasikan menjadi karya. Karya ini pun berangkat dari sebuah gagasan, yaitu "akibat buruk yang diterima seseorang ketika tidak menjalankan tugas dan kewajibannya dengan baik". Lebih jauh dijelaskan oleh Wahyudi (periksa Wayang Nusantara, Vol.1 No.1 2014: 10-11) bahwa dari gagasan tersebut dapat dibangun sebuah tema, yang kemudian dijabarkan menjadi rangkaian peristiwa dalam sebuah alur. Setiap peristiwa yang dialami oleh tokoh-tokohnya harus menampilkan masalah yang logis dalam sebuah setting tertentu. Oleh karena karya ini mengangkat kisah Tantri, maka penentuan setting tidak seketat dalam Mahabarata dan Ramayana.

Mengingat bahwa cerita Tantri ini berupa cerita tutur, bukan bentuk seni pertunjukan, maka untuk mentransformasikannya ke dalam pertunjukan wayang diperlukan pembangunan imajinasi. Imajinasi adalah daya untuk membentuk gambaran (imaji) atau konsep-konsep mental yang tidak secara langsung didapatkan dari sensasi (penginderaan) (Tedjoworo, 2001:21). Melalui imajinasi, pengkarya bisa membangun gambaran semua yang terjadi beserta settingnya pada tiap-tiap peristiwa yang dihadirkan dalam karya ini. Untuk konsep pertunjukannya, pengkarya terinspirasi oleh film "Toy Story", yang memadukan dunia anak-anak dan dunia mainan (boneka) dalam sebuah dunia baru yang menyatu, dalam sebuah realitas yang sama, yaitu memadukan tiga jenis wayang yang populer di Bali, yaitu wayang golek, wayang kulit, dan wayang lemah. Oleh karena itu, karya ini diberi nama "wayang fusi", yang artinya penggabungan, perpaduan atau penyatuan (Hasaan, 1996: 261). Ketiga jenis wayang tersebut disinergikan ke dalam sebuah karya wayang yang bernuansa inovatif, dengan tema cerita yang diambil dari lakon Tantri yang berjudul Wrémada. Penggabungan ketiga wayang tersebut didasarkan pada pakem pewayangan Bali.

Beberapa langkah yang dilakukan dalam mewujudkan wayang fusi adalah sebagai berikut. Pertama:berkaitan dengan bentuk wayang. Wayang yang digunakan dalam pertunjukan wayang fusi ini adalah wayang yang memiliki bentuk tiga dimensi atau wayang boneka yang dapat dimainkan seperti layaknya wayang golek. Bentuk wayang yang menyerupai golek ini akan dipadukan dengan wayang pipih, karena pertunjukan wayang fusi ini memadukan tiga jenis wayang yaitu Wayang Golek (Rod Puppet), wayang kulit (Shadow Puppet), dan 
Wayang Lemah. Kedua: berkaitan dengan topik. Oleh karena yang akan diangkat dalam wayang fusi adalah kritik sosial, maka dipilih cerita Tantri, yaitu cerita yang menggunakan tokoh-tokoh binatang sebagai pengungkap kritik maupun petuah (sesuluh). Tantri berasal dari bahasa Sanskerta 'tantri' yang salah satu artinya adalah nama tokoh utama dalam karya sastra mengenai kebijakan politik yang diilustrasikan dalam cerita dan dalam karya itu sendiri (Zoetmulder, 1995: 1202). Tantri yang merupakan karya sastra Jawa Kuna berbentuk puisi dan prosa, terdiri atas sejumlah dongeng yang menceritakan kisah tentang binatang atau fable. Pemahaman demikian berlaku dalam masyarakat Bali, yakni istilah tantri dipahami sebagai nama tokoh utama dalam sebuah karya sastra yang menceritakan tentang kehidupan binatang. Ketiga: teknik pemanggungan. Panggung dalam pertunjukan wayang fusi ini tidak menggunakan kelir sehingga penonton dapat menyaksikan figur-figur tokoh wayang yang dipertunjukkan secara langsung, tanpa harus menyaksikan bayangannya. Seperti teknik panggung pertunjukan Wayang Lemah yang dipentaskan pada siang hari tanpa menggunakan lampu blencong dan layar kain sebagai medium merefleksikan bayangan wayang. Teknik pencahayaannya menggunakan cahaya alam dan kelirnya menggunakan tiga gumpalan benang tembus yang dibentangkan dan diikat pada cabang kayu dadap yang dipancangkan di ujung sisi kiri dan kanan batang pohon pisang (gedebong) (Catra, 2013: 2). Keempat yang berkaitan dengan teknik permainan wayang (tetikesan), lighting, dan struktur penampilan.

Rancangan bentuk wayang tiga dimensi dengan cerita Tantri ini berupaya menghadirkan suguhan baru. Sebagai seni pertunjukan, maka penguasaan tehnik amat penting dalam penciptaan karya seni. Semakin mengenal dan menguasai tehnik seni, si seniman semakin bebas pula menuangkan segala aspek gagasan seninya. Gagasan yang bagus tanpa disertai penguasaan seni yang bagus pula dapat mengganggu kelahiran karya seni (Sumardjo, 2000: 96).

Tokoh utama dalam Wrémada adalah seekor monyet. Tantri adalah cerita yang kaya imajinasi dan fantasi. Ia menyajikan berbagai peristiwa yang sarat permasalahan dan sekaligus pemecahannya. Melalui cerita tentang kehidupan binatang, pembaca diantarkan untuk mengenal, menyelami dan memahami kehidupan alam sekitar (Taro, 2009). Wrémada ini, mengangkat permasalahan arogansi kepemimpinan di dalam mengambil keputusan maupun bertindak. Pemimpin yang memaksakan kehendak sendiri dan bersifat angkuh dalam mengemban jabatannya, serta melempar kesalahan pada orang lain; dan bahkan sering kali memerintah bawahannya dengan sewenangwenang. Monyet sebagai tokoh utama, mendapat mandat dari singa si raja hutan untuk menjaga ketertiban hutan. Dengan mandat tersebut, monyet berhak untuk mengatur dan memelihara keamanan serta ketertiban hutan. Dikisahkan bahwa si monyet sangat gegabah. Ketika ada keributan di dalam hutan, monyet langsung menyalahkan rakyat (para binatang), tanpa mengetahui duduk permasalahannya. Namun saat mengetahui akar permasalahannya, yakni berpangkal dari kesalahannya sendiri, monyet merasa menyesal.

Harapan penggarap, cerita tersebut dapat dijadikan cerminan bagi masyarakat, yaitu apabila mereka menjadi pemimpin dapat bersikap bijaksana dan berpedoman pada catur pariksa atau disebut juga dengan nama catur nayasandhi yaitu sama, beda, dana, dan danda (Ngurah, 1993: 194). Catur nayasandhi tersebut kiranya dapat dijadikan pedoman dan arahan yang bijaksana bila seseorang menjadi pemimpin, baik dalam bersikap atau bertindak ketika melaksanakan tugasnya. Konsep inilah yang menjadi ide dalam karya ini mengingat bahwa fenomena yang terjadi di zaman sekarang masih banyak sosok pemimpin yang semestinya mengayomi masyarakatnya, tetapi kenyataannya justru terjerat oleh beberapa kasus yang merugikan masyarakat bahkan negaranya sendiri. Nilai-nilai tersebut bersumber dari agama-agama besar dan dari karya seni yang mengandung ajaran-ajaran ketuhanan, filsafat, dan etika (Amir, 1991: 16). Wayang secara langsung merupakan wahana atau alat pendidikan watak yang menawarkan metode pembelajaran total tetapi nonformal.

\section{Proses Penggarapan Wayang Fusi}

Untuk mewujudkan karya ini, proses yang dilalui mengikuti model penciptaan seni yang dikemukakan Suteja, yakni meliputi ngarencana, nuasen, makalin, nelesi, dan ngebah (Suteja, 2012: 103). 


\section{Tahapan Ngarencana atau Perencanaan}

Tahap Ngarencana merupakan tahap perenungan secara intens tentang pencarian ide, tema serta membangun struktur dramatik sesuai tema dan penetapan berbagai aspek seni pertunjukan. Tahap ini diartikan sebagai menyediakan atau mempersiapkan bahan untuk melakukan proses. Ngarencana merupakan proses awal penjelajahan suatu ide yang direnungkan secara intens terhadap konsep-konsep pembentukan karya Wrémada.

Perencanaan dalam karya ini adalah mencari sumber cerita yang relevan dengan permasalahan yang akan diangkat dalam karya serta menarik untuk dituangkan kedalam pertunjukan. Berdasarkan percermatan dan pertimbangan, maka dipilih kisah dalam cerita Tantri. Untuk pendalaman materi cerita, pengkarya membaca buku-buku Tantri dan mengunjungi situs internet tentang kisahkisah binatang Bali. Dalam situs terdapat sebuah cerita menarik yaitu cerita Lutung Dadi Pecalang. Cerita ini mengisahkan tentang monyet yang diberi mandat oleh singa untuk menjaga hutan. Selama melaksanakan mandat, ada masalah yang membuat monyet marah. Masalah tersebut muncul disebabkan oleh ulah burung pelatuk, siput, kunang-kunang, kumbang tahi, dan ter-akhir sapi yang ternyata sembarangan membuang kotoran. Monyet yang mengetahui bahwa dirinya akan kalah melawan sapi, ia pun memanggil singa untuk mengalahkan sapi. Saat pertempuran akan dimulai sapi dibela oleh kadal, dan selanjutnya pertempuran pun tidak dapat dielakkan. Pada akhirnya singa mati, dan monyet lari tunggang langgang.

Untuk melengkapi dan memantapkan cerita ini dilakukan wawancara dengan para dalang. Anom Ranuara merupakan salah satu dalang yang diwawancarai. Anom Ranuara mengatakan bahwa cerita tersebut merupakan sastra lisan yang hidup dan berkembang di Bali, yang oleh masyarakat Bali lazim disebut satua silih dalih. Berbeda halnya I Ketut Merta, seorang dalang dari Buleleng, mengatakan bahwa tokoh dalam cerita tersebut ada kemiripan dengan tokoh dalam cerita Lutung Nyepi yang mengisahkan tentang monyet yang menjaga hutan pada saat Hari Raya Nyepi berlangsung. Namun para penghuni hutan melanggar aturan yang berlaku, di antaranya adalah: kunang-kunang meyalakan api, burung pelatuk membunyikan suatu alat musik, kumbang tahi melakukan suatu pekerjaan, sehingga hewan-hewan tersebut diadili oleh monyet. Meskipun kasusnya berbeda, namun pada hakikatnya kedua cerita tersebut memiliki kesamaan kapasitas bagi si monyet, yaitu monyet yang sedang memegang kekuasaan.

Selanjutnya, pengkarya menggabungkan kedua cerita tersebut di atas dan menginterpretasikan ulang ke dalam sebuah lakon baru yang diberi judul Wrémada. Meskipun temanya masih tetap, yaitu tentang kekuasaan, tetapi dilakukan perubahan pada kapasitas monyet sebagai pemegang kekuasaan. Apabila dalam dua cerita di atas, kera tidak mampu melaksanakan tugas dengan baik, maka dalam Wrémada monyet dikarakterkan sebagai tokoh yang mabuk kekuasaan. Perubahan karakter ini guna mengakomodasi berbagai fenomena kepemimpinan yang terjadi dewasa ini. Oleh karena itu, karya ini diberi judul Wrémada yang artinya monyet yang sedang mabuk, dalam arti mabuk kekuasaan sehingga sikapnya menjadi angkuh atau sombong. Pengertian 'mada' merujuk pada catur mada yang salah satunya yaitu aiswarya mada yang berarti mabuk akan kekuasaan. Penggarap ingin mengungkapkan sifat arogansi kepemimpinan di dalam mengambil keputusan maupun bertindak yang selalu memaksa kehendak sendiri, dan bersifat angkuh dalam mengemban jabatannya. Sosok pemimpin yang semestinya mengayomi masyarakatnya dengan benar, justru terjerat beberapa kasus yang merugikan masyarakat bahkan negaranya sendiri. Harapan penggarap cerita tersebut menjadi cerminan bagi masyarakat agar ketika menjadi pemimpin bersikap bijaksana dan berpedoman pada catur nayasandi yaitu sama, beda, dana, dan danda. Dengan pedoman tersebut seorang pemimpin mendapat arahan yang bijaksana, baik bersikap atau bertindak dalam melaksanakan tugasnya. Fenomena inilah yang menjadi ide yang ingin penggarap wujudkan, karena zaman sekarang banyak kasus tentang sosok pemimpin yang semestinya mengayomi masyarakatnya dengan benar, justru terjerat beberapa kasus yang merugikan masyarakat bahkan negaranya sendiri. Sifat arogan dalam kepemimpinan akan ditampilkan melalui gerak dan dialog sebagai aspek kehidupan sosial serta inovasi dalam teknik pentas sebagai landasan berkreativitas.

Ide penciptaan mengalami proses penyempurnaan melalui beberapa sumber pendukung karya 
seperti pengetahuan dalam bidang pedalangan, menonton berita tentang fenomena kepemimpinan, buku-buku kepustakaan yang menyangkut tentang kepemimpinan, teknik pentas, keterangan informan, beberapa video, rekaman wayang, dan sumber-sumber lain yang mendukung data. Dengan berbagai sumber tersebut penggarap mendapat gambaran yang jelas dan dijadikan konsep penciptaan wayang. Penyempurnaan konsep atau rancangan tertulis dilakukan guna mendapatkan suatu kesatuan antara ide, bentuk, dan penampilan. Rangkuman sumber dan seluruh unsur pendukung penciptaan karya Wrémada melahirkan tema arogansi dalam kepemimpinan.

\section{Tahapan Nuasen atau Persiapan}

Setelah perencanaan yang disusun dipandang cukup, maka tahap selanjutnya adalah nuasen, yaitu tahap upacara ritual yang dilakukan sebelum percobaan-percobaan, mencari gerak-gerak wayang sesuai dengan adegan, dialog wayang, musik iringan, dan lain-lain yang berkaitan dengan proses penciptaan karya Wrémada. Dalam tahap ini, penggarap melakukan persembahyangan pada hari Saniscara Wage, Dukut Tilem sasih Kewulu (Sabtu, 1 Maret 2014), yang dalam kepercayaan masyarakat Bali (primbon Bali) dipandang sebagai hari baik untuk memulai sebuah pekerjaan. Nuasen diikuti oleh seluruh pendukung garapan di merajan kampus ISI Denpasar dan penggarap melakukan persembahyangan khusus di rumah sendiri dengan menggunakan saran banten pejati atau sesaji sebagai perwujudan sembah bakti terhadap Ida Sang Hyang Widhi Wasa, Tuhan Yang Maha Esa agar seluruh proses karya Wrémada ini tidak ada halangan atau lancar sesuai dengan rencana.

\section{Tahapan Makalin atau Eksplorasi}

Tahap makalin yaitu proses pemilihan material yang mendukung terciptanya karya Wrémada. Material merupakan bakal yang dipakai sebagai bahan untuk membuat barang lain (Moeliono, 1998: 566). Keterampilan yang dibutuhkan dalam mendukung seni pedalangan meliputi tembang dan seni tabuh dijadikan pertimbangan dalam proses penciptaan karya seni pedalangan. Di samping itu, kemampuan improvisasi para pendukung karya ini sangat diperlukan. Improvisation mempunyai arti pembuatan (penyediaan) sesuatu berdasarkan bahan-bahan yang ada tanpa persiapan terlebih dahulu (Sugono, 2008: 529). Dalam penciptaan seni pertunjukan improvisation memberi kesempatan yang lebih besar bagi imajinasi, karena terdapat kebebasan yang lebih untuk meningkatkan diri penggarap. Dalam tahapan ini, seniman di Bali menyamakan tahapan tersebut dengan tahapan makalin. Unsur-unsur yang mendukung terciptanya karya Wrémada antara lain sebagai berikut.

1. Pemilihan pemain penggerak wayang.

Proses makalin merupakan suatu proses tindakan atas hasil eksplorasi yang dituangkan ke dalam konsep karya (Suteja, 2012: 106). Untuk mengimplementasikan ide ke dalam sebuah pertunjukan wayang diperlukan dukungan para pemain penggerak wayang yang memiliki keterampilan yang memadai serta pemahaman atas cerita agar mampu menerjemahkan ideide ke dalam pertunjukan wayang. Mengingat bahwa tokoh-tokoh dalam pertunjukan ini banyak melakukan gerakan bersama-sama, maka diperlukan beberapa pemain penggerak wayang. Selain itu, dalam karya ini dibutuhkan pendukung dengan gerak atau tetikesan yang bagus. Oleh karena itu untuk mendukung karya Wrémada ini, pengkarya memilih sekaa i pedalangan, yaitu sebuah perkumpulan mahasiswa Jurusan Pedalangan di ISI Denpasar yang sudah mempunyai talenta atau bakat dalam bidang pedalangan, yang sampai sekarang masih eksis dalam seni pedalangan. Para pemain penggerak wayang dapat dilihat pada gambar 1 .

2. Pemilihan penabuh.

Musik memberikan rangsangan mengungkapkan suatu suasana dan mempertegas aksen, pencapaian tema, oleh karena itu pemilihan pendukung harus mempertimbangkan mereka yang masih memiliki kepekaan dalam tempo,

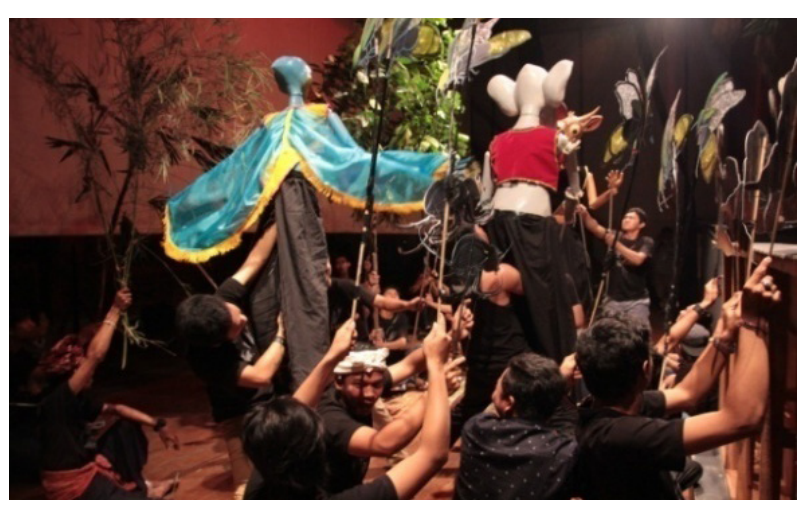

Gambar 1. Sekaa i pedalangan pemain penggerak wayang. 
dinamika, dan irama (Suteja, 2012:109). Pendukung musik iringan ini adalah "Palawara Music Company" pimpinan I Wayan Ari Wijaya, S.Sn yang beralamat di Jalan Narakusuma Gg. XVI No. 2, Br. Sebudi, Desa Adat Tanjung Bungkak, desa Sumerta Kelod, Denpasar, Bali. Penabuh musik iringan karya Wrémada berjumlah 10 (sepuluh) orang laki-laki dan wanita termasuk gerong. Pemilihan para penabuh disesuaikan dengan kebutuhan instrument yang digunakan dan kemampuan untuk memainkan alat musik seperti gong kebyar, keyboard, bass, drum, dan lain-lain. Para penabuh dan alat musik yang digunakan dapat dilihat pada gambar 2 .

3. Pemilihan tempat latihan.

Hal yang paling menentukan dalam kelancaran proses karya adalah tempat latihan. Oleh karena itu tempat latihan perlu suasana yang nyaman dan kondusif, strategis, serta sarana dan prasarananya memadai. Untuk itu tempat latihan yang dipilih adalah gedung Candrametu ISI Denpasar. Tempat latihan ini sangat mudah dijangkau oleh para pendukung, mengingat tempat latihan merupakan salah satu gedung yang berada di kampus ISI Denpasar yang menjadi tempat perkuliahan pendukung karya ini. Tempat latihan disesuaikan dengan stage atau panggung yang mendekati tempat pementasan karya Wrémada agar menjadi suatu kebiasaan bersikap bagi para dalang untuk keluar masuknya wayang. Sikap tersebut dapat memberikan manfaat bagi perkembangan proses pembentukan karya sesuai dengan konsep penciptaan.

4. Pembuatan wayang.

Pembuatan wayang menjadi salah satu usaha kreatif yang berguna sebagai langkah persiapan dalam proses penciptaan karya

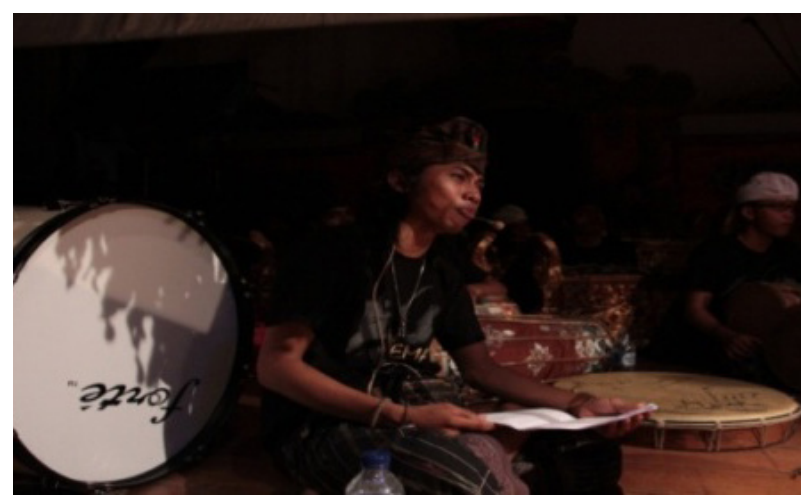

Gambar 2. Pengiring wayang Wrémada. pewayangan. Proses ini memiliki nilai khusus, karena memerlukan imajinasi dalam membangun karakter tokoh-tokohnya. Proses pembuatan wayang ini berpijak pada bentukbentuk binatang dalam Wayang Tantri karya I Wayan Wija yaitu wayang berkepala binatang namun tubuhnya manusia dalam wujud tiga dimensi. Bahan yang dipilih adalah kayu jenis kayu kanjimas sebagai kerangka dasar, gabus sebagai bahan pokok pembuatan kepala dan badan wayang. Setelah wayang terbentuk dilanjutkan dengan pengolesan plamir tembok yang dicampur dengan lem fox agar plamir merekat dengan bagus. Plamir yang sudah mengering akan diamplas supaya halus agar memberikan dampak pada bentuk yang sempurna seperti yang diinginkan. Penyelesaian akhir dilakukan dengan menggunakan airbrush sesuai dengan warna kulit karakter hewan pada umumnya. Selain wayang tiga dimensi tersebut, ada juga pembuatan wayang dengan jenis wayang pipih (dua dimensi) yang terbuat dari bahan kertas duplek dengan proses pembuatannya sama dengan proses pembuatan wayang kulit. Tahap pembuatan wayang dapat dilihat pada gambar 3 .
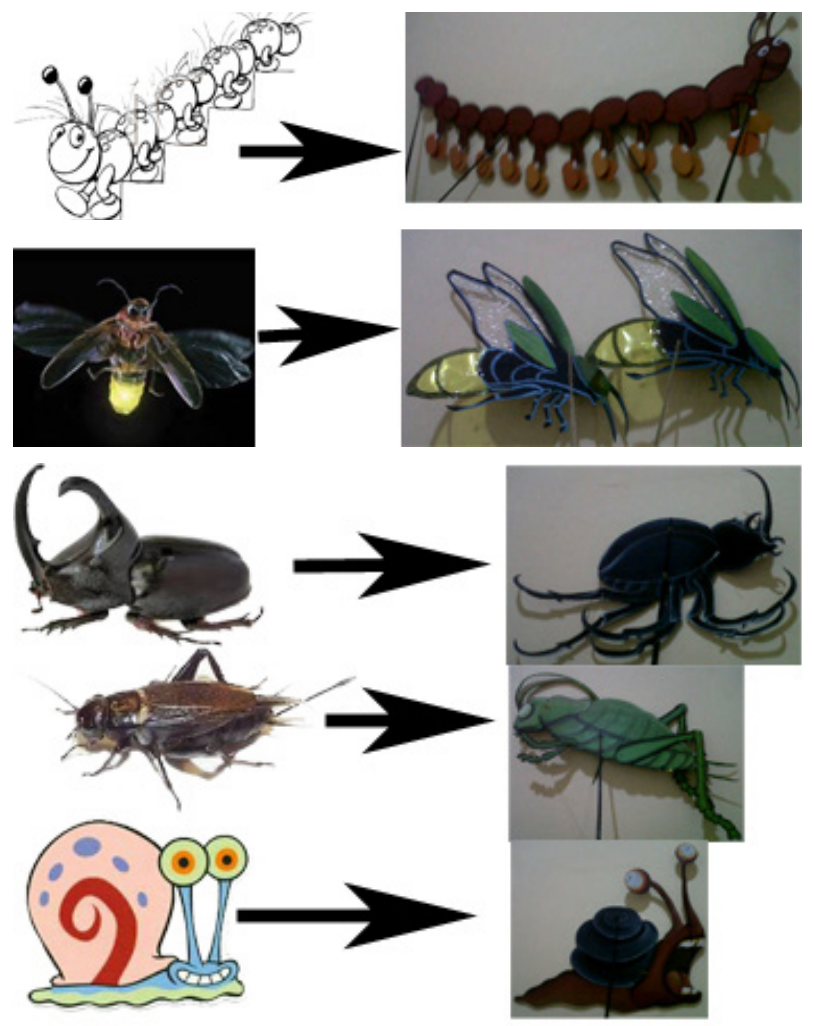

Gambar 3. Proses pembuatan wayang, dari melihat gambar hewan lalu dibuat wayang. 
Wujud dari wayang ini merupakan hasil deformasi bentuk wayang yang sudah ada, yang artinya mengubah bentuk atau wujud dari yang baik menjadi kurang baik (Sugono, 2008: 304). Deformasi bentuk lebih kepada kreativitas dalam pembuatannya untuk meonjolkan karakter yang diinginkan serta agar lebih menarik dan unik untuk ditonton. Deformasi dilakukan pada bentuk kepala yang lebih besar dan tidak sesuai dengan bentuk tubuhnya. Berikut nama-nama wayang yang akan digunakan dalam garapan Wrémada.

Wayang tiga dimensi terdiri dari: (1) Bojog; (2) Sapi; dan (3) Burung Pelatuk. Wayang dua dimensi terdiri dari: (1) Singa; (2) Kumbang tahi; (3) Siput; (4) Kunang-kunang; (5) Jangkrik; (6) Lipan; (7) Tai; (8) Monyet; (9) Burung 3 jenis; (10) Bebek; (11) Bangau; (12) Anjing; (13) Badak 2 jenis; (14) Kelinci 2 jenis; (15) Rusa; (16) Kambing; (17) Babi; (18) Gajah; (19) Macan. Beberapa tokoh yang diciptakan dapat dilihat pada gambar 4 (tokoh Kera), gambar 5 (tokoh Sapi), dan gambar 6 (tokoh Burung Pelatuk).

\section{Tahapan Nelesin atau Pembentukan (Forming)}

Nelesin adalah proses pembentukan, hasil dari proses makalin yang telah dipastikan mendapatkan wujud wayang, pengorganisasian kedalam bentuk yang dapat mendukung atau menyatukan tematik, dramatik, dan teatrikal sehingga karya mampu mengekspresikan gagasan pengkarya. Tujuan dari suatu proses adalah menyimpulkan pengalamn-pengalaman yang terarah menuju pembentukan karya seni (Suteja, 2012: 117). Hasil dari pembentukan merupakan hasrat untuk mewujudkan suatu yang ditemukan dan proses yang paling penting yaitu penggabungan atau penyatuan jenis-jenis wayang, cerita, dan stuktur pertunjukan agar bersinergi. Setelah tahapan nelesin selesai, dan sudah mampu untuk menggabungkan semua elemen-elemen tersebut, para seniman Bali melanjutkan dengan tahap ngebah untuk mengetahui wujud karya yang akan di tampilkan.

Tahapan pembentukan dilakukan setelah latihan sektoral berjalan, yaitu mulai menggabungkan gerak wayang, vokal, dan iringan peradegan. Adapun tujuan penggabungan ini ialah untuk mendapatkan gambaran garapan secara utuh. Untuk itu eksplorasi dan evaluasi terus dilakukan dalam rangka mengatasi berbagai kelemahan sampai diperoleh hasil, baik gerak wayang, bloking, maupun unsur-unsur dramatik yang diinginkan. Tahapan ini, oleh seniman Bali disamakan dengan tahap nelesin. Tahapan ini juga merupakan proses terakhir untuk merangkum seluruh hasil tahap makalin.

\section{Tahapan Ngebah}

Untuk mengetahui wujud karya secara utuh, diadakan pementasan atau ngebah. Ngebah adalah pementasan pertama dari sebuah hasil karya seni. Pementasan ini bertujuan untuk mengevaluasi atau mengadakan perubahan-perubahan yang penting dalam karya seni (Suteja, 2012: 133). Evaluasi dilakukan mulai dari tema, alur cerita, musik iringan, dan gerak wayang yang belum maksimal. Ngebah juga berperan untuk memberikan motivasi atau menumbuhkan keyakinan dan meningkatkan mental para pendukung dalam menyajikan karya seni. Pertunjukan perdana atau tahap ngebah wayang fusi ini dilakukan pada hari Jumat, 25 April 2014 di Natya Mandala ISI Denpasar. Hasil evaluasi dari tahap ngebah ini ialah karakterisasi dari masing-masing wayang dan teknis panggung perlu dimantapkan.

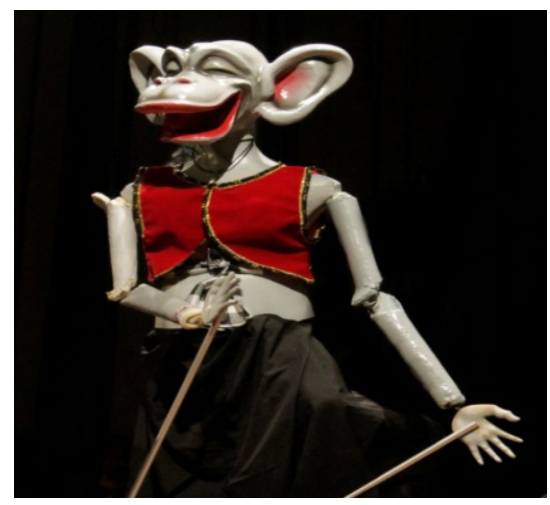

Gambar 4. Tokoh kera.

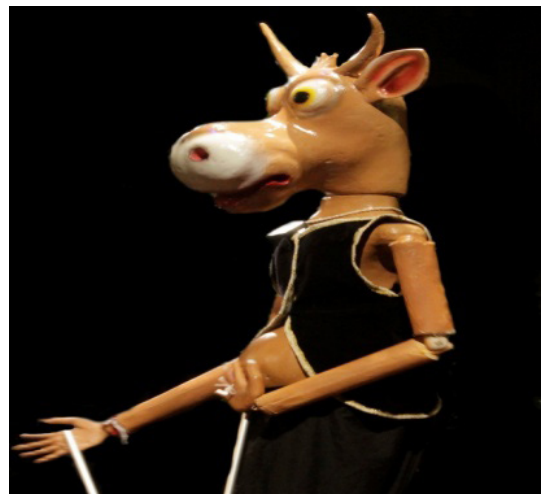

Gambar 5. Tokoh sapi.

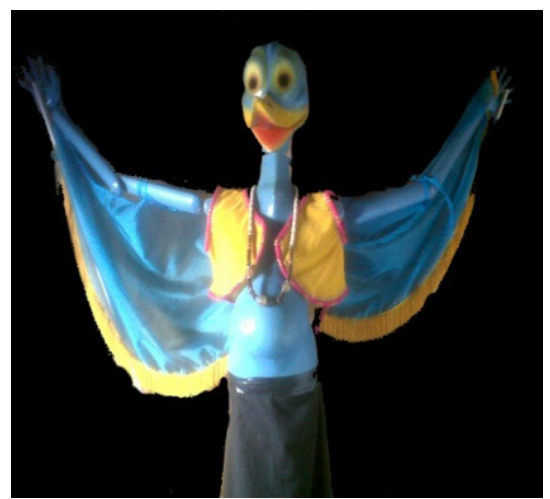

Gambar 6. Tokoh burung pelatuk. 


\section{Ikhtisar Lakon}

Cerita ini diawali dengan kisah seekor Bojog yang menjadi penjaga di dalam hutanWanakerta. Si Bojog yang mengemban tugas untuk menjaga ketentraman hutan langsung memantau keadaan hutan dengan cara memanjat, menggelayut, dan melompat di antara pepohonan tinggi di hutan. Saat memantau, Bojog melihat Sapi yang sedang makan di lahan berumput lebat. Dari sana muncul ide Bojog untuk memanfaatkan kotoran Sapi. Bojog mendatangi Sapi dan bermaksud meminta kotorannya untuk dijadikan pupuk. Bojog memerintahkan Sapi untuk menaruh kotorannya di tengah jalan, agar Bojog gampang untuk mengambilnya. Sapi yang baru mengetahui jika Bojog diberikan kuasa oleh Singa sebagai pamong hutan, mengiyakan permintaan Bojog. Bojog pun kembali memantau keberadaan hutan.

Setelah beberapa lama Bojog memantau hutan, dia merasa kelelahan lalu beristirahat di bawah pohon nagasari hingga tidur nyenyak. Saat tidur pulas, Bojog bermimpi saat ia diberi mandat untuk menjaga ketentraman Wanakerta oleh Singa sang Raja. Si Bojog dipilih karena ia dianggap mampu memantau hutan melalui pohon yang tinggi, bisa memantau dari bawah, gerak-geriknya gesit, dan mempunyai keberanian menyelesaikan masalah. Namun, ketika Bojog tertidur pulas, datanglah Burung Belatuk (Atuk) lalu memukul pohon dan menimbulkan suara ribut. Bojog terbangun kaget, seketika mendamprat Atuk. Atuk menerangkan bahwa ada keributan antara teman-teman Siput di dekat danau yang berbondong-bondong membawa rumahnya. Kemudian Bojog mencari Siput yang sedang berbondong-bondong menjauh dari danau sambil meminta tolong. Bojog pun menghampiri sambil menanyakan masalahnya. Siput dan kawankawannya menjelaskan bahwa mereka tidak bisa tidur di malam hari karena setiap malam Kunangkunang selalu terbang di atas rumahnya sambil membawa lampu. Karena takut akan kebakaran, maka ia pun memutuskan untuk pindah dari danau itu. Sambil ngedumel, Bojog marah mencari Kunang-kunang. Begitu bertemu dengan Kunangkunang yang sedang terbang, Bojog langsung memarahinya. Kunang-kunang menghampiri Bojog dan menjelaskan bahwa mereka melakukan itu karena Beduda dan teman-temannya melubangi jalan tanah secara acak, makaKunang-kunang dan teman-temannya bermaksud menerangi jalan, agar tidak ada hewan yang jatuh ke lubang tersebut. Lagi-lagi Bojog marah dengan Beduda. Ia langsung mencari Beduda dan ingin menghukumnya. Bojog yang sedah jengkel, begitu bertemu dengan Beduda dan teman-temannya, langsung memarahinya. Beduda dan teman-temannya yang merasa tidak bersalah balik memarahi Bojog, serta menjelaskan duduk permasalahannya. Mereka menggali lubang karena Sapi buang kotorannya di sembarang tempat. Bojog naik pitam dan marah besar dengan Sapi. Bojog segera mencari Sapi dan melihat bukti banyak kotoran Sapi berserakan di manamana. Bojog pun ngamuk dan memarahi serta berkelahi dengan Sapi. Bojog dapat dikalahkan oleh Sapi. Setelah perkelahian tersebut selesai, dengan tenang Sapi menjelaskan kepada Bojog, bahwa Bojog sendirilah yang memerintahkan Sapi untuk buang kotoran di tengah jalan, karena Bojog berkepentingan dengan kotoran Sapi guna memupuk kebun pisang dan tanaman yang menjalar di sekitar kebunnya. Penjelasan Sapi disaksikan oleh Belatuk, Tumisi, Kunang-kunang, Beduda dan Lipan yang mendukung Sapi, karena dengan kotoran si Sapi, mereka mampu hidup tentram. Mendengar penjelasan tersebut Bojog merasa bersalah dan segera minta maaf. Ia lupa akan permintaannya kepada Sapi. Oleh karena Bojog sibuk dengan tugasnya, maka ia lupa untuk mengambil kotoran Sapi untuk dijadikan pupuk tanaman pisangnya.

\section{Struktur Drama}

Lakon wayang sebagai drama, ia memiliki struktur yaitu relasi antar unsur. Oleh karena drama merupakan aksi yang hidup, maka unsurnya meliputi babak, adegan, dialog (percakapan yang dilakukan oleh dua orang atau lebih), monolog (percakapan oleh satu tokoh), prolog (penutup dalam drama) (Endraswara, 2011: 23). Kelima struktur tersebut saling berelasi satu sama lain membangun sebuah rangkaian peristiwa. Berikut pembabakan struktur drama dalam karya Wrémada. Babak I

Anak-anak beramai-ramai bersama temantemannya bermain dengan boneka Bojog di dalam ruangan. 
Anak-anak mengikat kain poleng pinggang boneka Bojog, dan kemudian keluar ruangan karena dipanggil oleh ibunya untuk segera mandi. Gambar 7 memperlihatkan adegan anak-anak yang sedang bermain boneka Bojog di babak pertama.

\section{Babak II}

Dengan pelan-pelan mainan boneka Bojog hidup berjalan sambil meloncat-loncat.

Bojog bertemu dengan sapi. Bojog meminta kotoran sapi untuk dijadikan pupuk di kebunnya. Bojog kembali berjaga-jaga sambil memeriksa hutan. Bojog beristirahat dan tertidur pulas.

Bojog tertidur dan bermimpi ketika menghadap Raja Singa. Bojog diberi mandat oleh Raja Singa sebagai pamong untuk menjaga ketentraman Wanakerta dengan tanda Aji Lingsana. Dia diberi mandat sebagai pamong karena dianggap mampu memanjat, bergelantungan di antara pohon untuk memantau hutan, meloncat, melihat keadaan dari atas maupun bawah, dan berani menyelesaikan masalah dengan tegas.

\section{Babak III}

Saat Bojog sedang tidur pulas, datanglah burung Pelatuk dengan tergesa-gesa sambil memukulmukul pohon kayu, mengisyaratkan adanya keributan di hutan. Bojog yang sedang istirahat mendengar hal tersebut seketika marah dan langsung memarahi Pelatuk. Pelatuk menjelaskan kepada Bojog bahwa ada suatu kejadian di dekat danau. Siput (Tumisi) dengan teman-temannya lari berbondong-bondong menjauhi danau. Bojog mendatangi Siput dengan teman-temannya, dan menjelaskan bahwa Kunangkunang dan teman-temannya membawa api di atas rumah siput, sehingga mereka takut rumahnya akan terbakar. Bojog sambil marah-marah bertemu dengan Kunang-kunang dan teman-temannya yang sedang terbang. Kunang-kunang menghampiri Bo-

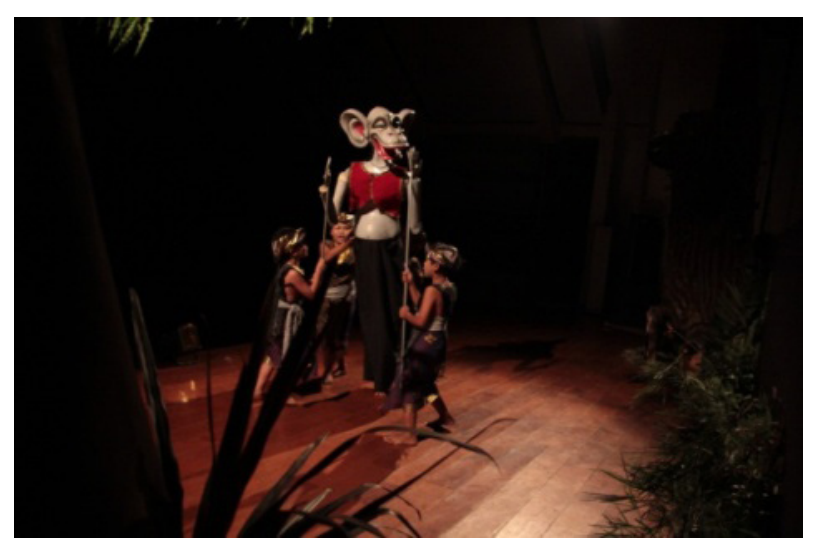

Gambar 7. Pemain anak-anak pada adegan pertama. jog dan menjelaskan bahwa mereka melakukan itu karena Beduda dan teman-temannya melubangi jalan tanah secara acak. Bojog makin marah lalu segera menemui Beduda dan teman-temannya, serta menanyakan alasan Beduda membuat lobang di tengah jalan. Beduda dan teman-temannya menjelaskan bahwa mereka menggali lobang karena Sapi buang kotoran secara sembarangan bahkan di tengah jalan. Sambil mencak-mencak marah Bojog segera mencari tempat Sapi berada, dan dilihatnya Sapi sedang buang kotoran di tengah jalan.

\section{Babak IV}

Tanpa basa-basi Bojog langsung marah dan melemparinya dengan ranting kayu sehingga terjadi perang fisik dengan Sapi. Bojog dapat dikalahkan oleh Sapi. Sapi membela diri. Ia menjelaskan duduk persoalan yang sebenarnya dan disaksikan oleh seluruh binatang yang mendukung pernyataan dan kebenaran Sapi. Bojog merasa bersalah dan terdiam. Seluruh binatang menghilang, yang tinggal hanyalah Bojog yang terdiam dan kembali menjadi boneka.

\section{Babak V}

Anak-anak memasuki kamar lalu mengambil dan melepas kain poleng yang telah diikatkan di pinggang boneka Bojog.

\section{Plot atau Alur}

Plot atau alur adalah perjalanan dari jalinan peristiwa. Keberadaannya sangat penting dalam suatu cerita, karena tanpa penggarapan alur yang baik, drama sering menjemukan atau terasa datar (Endraswara, 2011: 24). Plot atau drama cerita akan mengantarkan lakon menjadi menarik. Dalam cerita Wrémada ini, penggarap ingin memaparkan plot drama (dramatic-line) yang ditemukan oleh Hudson yakni terdiri dari lima (5) bagian berikut. 1. Eksposisi.

Eksposisi adalah uraian atau bagian dari karya sastra (Moeliono, 1998: 222). Sesuai dengan kedudukannya, eksposisi memberikan penjelasan atau keterangan mengenai berbagai hal yang diperlukan untuk memahami peristiwaperistiwa berikutnya dalam cerita. Keteranganketerangan tersebut dapat mengenai tokohtokoh cerita, masalah yang timbul, tempat, dan waktu ketika cerita terjadi, dan sebagainya (Endraswara, 2011: 29). 
Pengenalan masalah dalam cerita Wrémada ini dimulai dari sikap kepemimpinan Bojog yang menyuruh Sapi untuk meletakkan kotorannya di ditengah jalan dengan tujuan agar Bojog tidak bingung mencari kotoran tersebut. Kotoran sapi ini akan dipakai untuk pupuk di kebunnya. Adegan ini jelas memperkenalkan tokoh utama yaitu Bojog dan masalah yang ditimbulkannya dalam memimpin hutan. Penggambaran ini diwujudkan melalui percakapan dan gerak wayang yang tertera dalam pertunjukan wayang ini.

2. Komplikasi.

Komplikasi atau penggawatan merupakan lanjutan dari eksposisi. Dalam bagian ini, muncul seorang tokoh cerita yang mulai mengambil prakarsa demi mencapai tujuan tertentu. Akan tetapi, hasil dari prakarsa tersebut tidak pasti, dengan demikian timbullah penggawatan (Endraswara, 2011: 33).

Bojog dalam karya pewayangan Wrémada ini berniat menjaga hutan dengan caranya sendiri, akan tetapi prakarsanya belum tentu berhasil karena beberapa hal. Beberapa hal itu antara lain Bojog memiliki sikap arogansi dan ego yang tinggi dalam memimpin. Kegawatan ini semakin meningkat saat sikap arogansi tersebut mendatangkan masalah di dalam hutan yaitu dimulai dari si Pelatuk membawa berita bahwa kawanan Siput lari tunggang langgang dari daerahnya. Bojog yang bertanggung jawab atas keamanan hutan langsung menemui kawanan Siput dan seterusnya sampai Bojog bertemu dengan Sapi.

3. Klimaks.

Klimaks merupakan puncak dari suatu hal, kejadian, keadaan, dan sebagainya, berkembang secara berangsur-angsur (Moeliono, 1998: 446). Dalam proses klimaks inilah adanya suatu kejadian atau adegan paling menarik, gawat, penting serta menjadi sebuah tolok ukur para penggarap untuk menuangkan pesan-pesan yang ingin disampaikan pada penikmat seni.

Proses Klimaks dalam garapan ini dibagi menjadi dua bagian yaitu klimaks menyusul komplikasi dan klimaks disusul resolusi. Klimaks menyusul komplikasi atau penggawatan, bagian ini pihak-pihak yang bertentangan atau berlawanan berhadapan untuk melakukan perhitungan terakhir yang menentukan (Endraswara, 2011: 30). Pada cerita Wrémada, klimaks terjadi pada bagian ketika Bojog dibangunkan oleh Pelatuk saat terjadi kerusuhan oleh Siput, Kunang-kunang, dan Beduda, namun persentase klimaksnya masih kecil dan belum pada titik tertinggi klimaks (turning-point). Penggawatan terakhir terjadi saat pertemuan Bojog dengan Sapi yang disusul dengan perkelahian fisik antara mereka. Klimaks disusul resolusi, pada bagian ini semua masalah yang ditimbulkan oleh prakarsa tokoh mulai menemukan pemecahannya. Resolusi dalam hal ini disebut juga peleraian atas masalah yang ditimbulkan, sehingga sudah dapat diketahui akhir dari cerita (Endraswara, 2011: 30). Dalam cerita Wrémada jelas bahwa klimaks disusul resolusi terdapat saat pertengkaran batin antara Bojog dan Sapi. Bagian tersebut akan membeberkan sikap arogansi Bojog dan menjelaskan bagaimana sepatutnya menjadi pemimpin dengan didukung beberapa tokoh hewan untuk mempertegas klimaks cerita.

4. Resolusi.

Resolusi merupakan putusan atau kebulatan pendapat berupa permintaan atau tuntutan yang ditetapkan oleh rapat musyawarah atau sidang (Moeliono, 1998: 745). Resolusi sebaiknya tidak menimbulkan pertanyaan janggal, yang artinya penyelesaian akhir sesuai dengan alur cerita agar maksud yang disampaikan mampu diterima oleh penonton. Dalam cerita Wrémada ini, resolusi nampak pada petanglian Bojog dengan Raja Singa yang ditandai oleh kembalinya sabuk yang diberikan. Bojog menyerahkan sabuk tersebut karena sudah tidak mampu lagi mengemban tugas atas dasar musyawarah para hewan di hutan.

5. Konklusi.

Konklusi disebut juga dengan kesimpulan cerita yang ditandai oleh tokoh Bojog merasa dikucilkan oleh para hewan akibat ulahnya yang telah menggunakan kekuasaan secara sewenangwenang. Bojog menyesali perbuatannya dan terus merenung dalam kesendiriannya.

\section{Tata Pentas}

Pentas merupakan unsur paling penting dalam seni pertunjukan. Melalui pentas itulah sebuah 
gagasan dapat teraktualisasikan. Oleh karena itu diperlukan sebuah tempat yang disebut panggung yang pada umumnya dibuat dengan posisi lantaiyang lebih tinggi dibandingkan penonton (Moeliono, 1998: 668). Dalam pentas sering ditampilkan ragam seni dan sastra seperti prosa dan puisi, serta adanya keunikan tersendiri saat penampilannya. Berbagai nilai dikembangkan dalam pentas sehingga benar-benar menjadi pementasan yang bermakna. Nilai penting dalam pentas antara lain: (a) memperluas budaya seseorang, (b) menguatkan diri, (c) mengembangkan imajinasi positif, (d) memupuk nilai moral agar penonton lebih humanitis (Endraswara, 2011: 34). Untuk tujuan tersebut, maka panggung perlu ditata sedemikian rupa, baik penataan properti, dekorasi, tempat atau posisi tokoh-tokohnya, maupun tata lampunya. Tokoh sebagai media untuk menyampaikan cerita serta pesan-pesan yang ingin diungkapkan, sedangkan peralatan teknis sebagai pendukungnya. Untuk menghidupkan tokoh dalam pentas, seluruh peralatan pentas sangat mendukung suasana. Peralatan tersebut meliputi:

1. Pengaturan panggung (stage).

Tata panggung juga terkait dengan tata artistik yang membentuk sebuah struktur yang jelas sehingga memunculkan imajinasi para penonton (Endraswara, 2011: 35). Dalam pertunjukan wayang Wrémada ini menggunakan

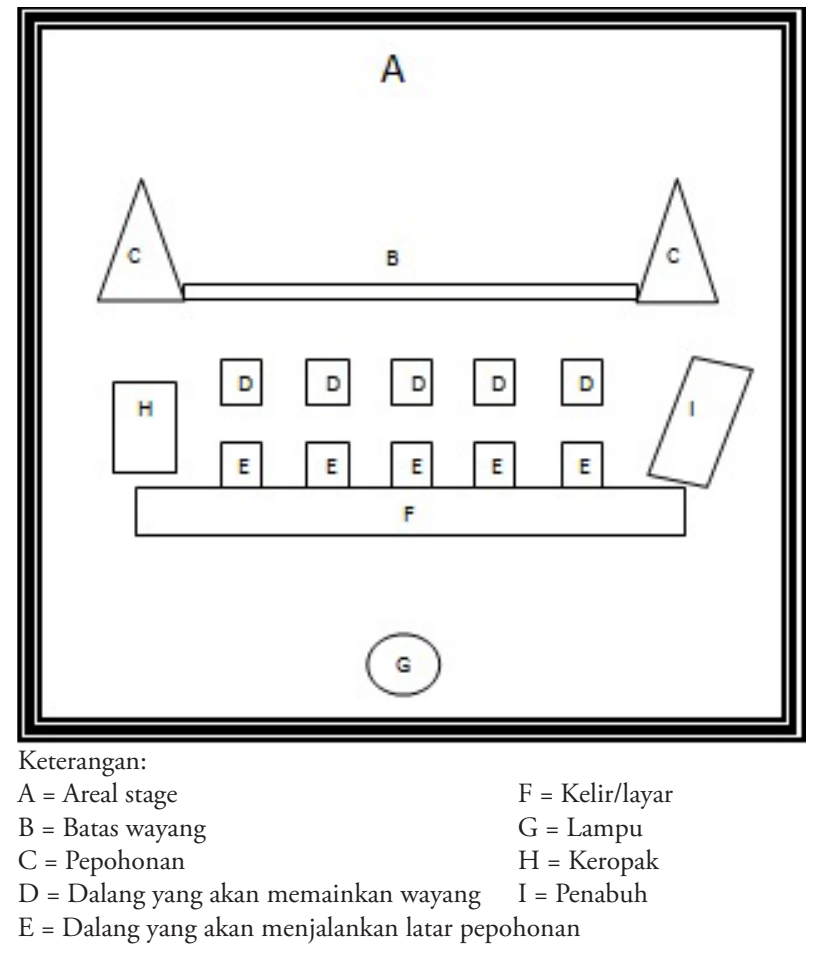

Gambar 8. Skema tata panggung (stage). tata panggung pementasan wayang golek yaitu tanpa menggunakan media kelir sebagai proyeksi bayangan. Panggung prosenium merupakan panggung konvensional yang memiliki ruang prosenium atau suatu bingkai gambar melalui mana penonton menyaksikan pertunjukan. Hubungan antara panggung dan auditorium dipisahkan atau dibatasi oleh dinding atau lubang prosenium. Sedangkan sisi atau tepi lubang prosenium bisa berupa garis lengkung atau garis lurus yang dapat disebut dengan pelengkung prosenium (Proscenium Arch). Skema tata panggung pementasan wayang Wrémada dapat dilihat pada gambar 8 .

Panggung prosenium dibuat untuk membatasi daerah pemeranan dengan penonton. Arah dari panggung ini hanya satu jurusan yaitu ke arah penonton saja, agar pandangan penonton lebih terpusat ke arah pertunjukan. Para pemeran diatas panggung juga agar lebih jelas dan memusatkan perhatian penonton. Dalam kesadaran itulah maka keadaan pentas prosenium harus dapat memenuhi fungsi melayani pertunjukan dengan sebaik-baiknya.

Dengan kesadaran bahwa penonton yang datang hanya bermaksud untuk menonton pertunjukan, maka harus dihindari sejauh mungkin apa yang nampak dalam pentas prosenium yang sifatnya bukan pertunjukan. Maka dipasanglah layar-layar (curtain) dan sebeng-sebeng (side wing). Maksudnya agar segala persiapan pertunjukan dibelakang pentas yang sifatnya bukan pertunjukan tidak dilihat oleh penonton. Pentas prosenium tidak seakrab pentas arena, karena memang ada kesengajaan atau kesadaran membuat pertunjukan dengan ukuran-ukuran tertentu. Ukuran-ukuran atau nilai-nilai tertentu dari pertunjukan itu kemudian menjadi konvensi. Maka dari itu pertunjukan yang melakukan konvensi demikian disebut dengan pertunjukan konvensional.

\section{Dekorasi.}

Pementasan karya ini diperlukan latar belakang suasana yang mendukung keadaan di pentas. Latar belakang tersebut harus bermakna dan biasanya disebut dengan scenery yaitu latar belakang dimana pentas diadakan untuk mempertunjukkan lakon. Scenery meliputi segala macam hiasan dan lukisan yang mempunyai keter- 
kaitan dengan lakon dari cerita (Endraswara, 2011: 111). Pertunjukan wayang Wrémada ini menggunakan scenery di daerah tertutup dengan meniru alam atau tempat seperti aslinya dan berhubungan dengan seni lukis.

Dekorasi dalam pementasan wayang Wrémada ini menggunakan ekspresionalisme exterior setting yaitu pentas panggung dekorasi alam terbuka dengan berusaha mengekpresikan atau bebas mengungkapkan kehendak sesuai de ngan tafsiran terhadap lakon (Endraswara, 2011: 115). Ekspresi terhadap dekorasi alam dituangkan dengan bentuk pepohonan yang dirancang seperti mainan agar latar pepohonan dengan wayang golek sebagai mainan menyatu. Latar pepohonan dimainkan bergerak melawan arah pandang wayang agar wayang terlihat berjalan. Adapun beberapa tanaman yang mendukung dekorasi pertunjukan seperti rumput-rumputan ditempel pada depan dan pembatas wayang, akar pohon beringin yang digantung di atas panggung,tanaman menjalar, dan pepohonan lain yang menghiasi sebelah kanan dan kiri panggung. Gambar 9 memperlihatkan dekorasi pementasan wayang Wrémada.

3. Tata lampu (lighting).

Lampu harus ditata dengan baik dan bukan hanya sebagai penerangan, tetapi mempunyai banyak fungsi seperti pengilustrasian (hiasan) atau penunjuk waktu (pagi, siang, sore dan malam) dan penerangan terhadap pentas aktor sehingga penonton dapat melihat dengan jelas bagian-bagian yang ditonjolkan dalam pertunjukan, membantu menerangi

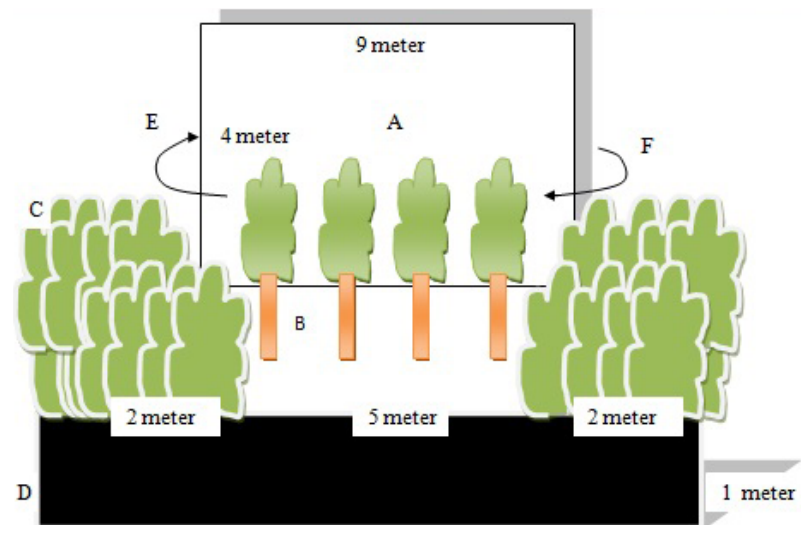

Keterangan:

$\mathrm{A}=$ Kelir/layar

$\mathrm{B}=$ Latar pepohonan

$\mathrm{D}=$ Batas wayang

$\mathrm{C}=$ Pepohonan

$\mathrm{E}=$ Arah masuknya latar pepohonan

$\mathrm{F}=$ Arah keluarnya latar pepohonan

Gambar 9. Sketsa dekorasi pementasan wayang Wrémada. dekorasi atau scenery. Pemilihan efek warna juga berperan penting dalam tata lampu sebagai pengekspresian mood guna mengungkapkan suasana dan adegan dalam cerita (Endraswara, 2011: 108).

Dalam pertunjukan wayang Wrémada ini menggunakan strip light, yaitu penataan lampu yang berderetan dan disusun dalam kotak khusus yang mampu memancarkan sinar dengan terarah dan diletakkan di atas panggung pentas, digantung di belakang pembatas atau sering disebut borderlight (Endraswara, 2011: 108). Lampu ini mengarah pada semua adegan dengan intensitas pencahayaan sesuai dengan adegan. Tentang tata lampu saat pementasan dapat dilihat pada gambar 10. Pertunjukan ini juga menggunakan spot light, yaitu lampu dengan sinar yang kuat dan berguna untuk memberikan sinar pada satu titik (Endraswara, 2011: 108). Lampu ini akan menyoroti tokoh Bojog dalam adegan Bojog yang sedang menyesali nasibnya telah bertindak sewenang-wenang saat masih memegang mandat yang diberikan oleh Singa. Tata lampu dalam adegan ini dapat dilihat pada gambar 11 .

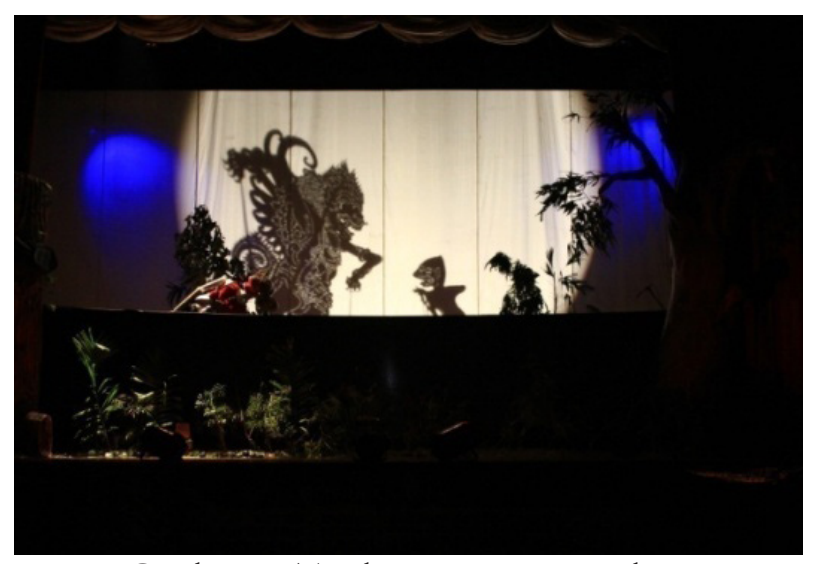

Gambar 10. Tata lampu saat pertunjukan.

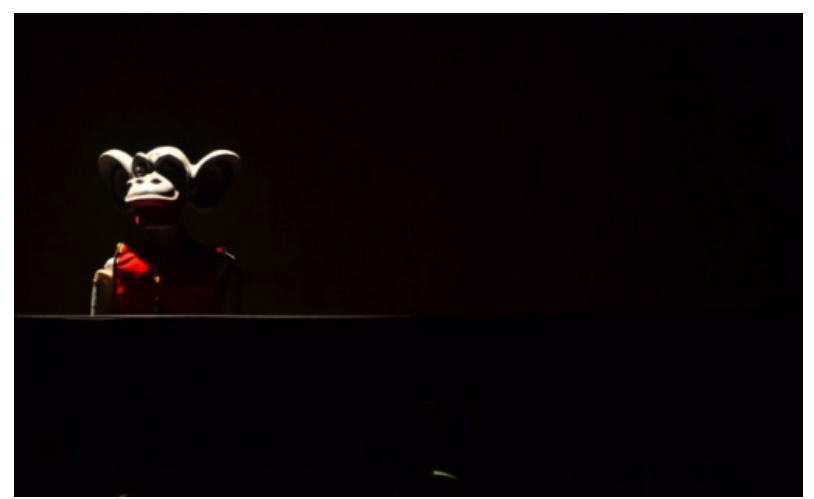

Gambar 11. Spot light menyoroti tokoh Bojog yang sedang menyesali nasibnya. 
4. Tata iringan.

Iringan dalam pertunjukan wayang kulit Bali merupakan salah satu komponen penting yang dapat memberikan warna sebuah pertunjukan. Iringan yang digunakan dalam garapan ini adalah gambelan Gong Kebyar serta ditambah dengan alat musik modern seperti keyboard dan bass drum. Kolaborasi ini dipilih untuk menciptakan suasana keagungan hutan ditambah dengan efek suara hewan dan suasana hutan.

\section{Penutup}

Garapan seni pakeliran dengan judul "Wrémada" ini merupakan sebuah garapan yang mengadopsi pola-pola film kartun barat yang berjudul Toy Story, dimana boneka hidup layaknya manusia. Garapan ini menggabungkan tiga jenis wayang yang berbeda yaitu Wayang Golek (Rod Puppets), Wayang Peteng (Shadow Puppet), dan Wayang Lemah. Ketiga jenis wayang tersebut memiliki teknik bermain yang berbeda dan memiliki ruang gerak yang berbeda pula. Dalam hal ini penggarap ingin menggabungkan ketiga jenis wayang tersebut, beserta teknik permainannya menjadi suatu garapan yang utuh ke dalam wujud seni pertunjukan wayang fusi. Yang dimaksud Wayang Fusi dalam garapan ini ialah penggabungan atau perpaduan tiga jenis wayang yaitu Rod Puppet (Wayang Golek), Shadow Puppet, dan Wayang Lemah. Ketiga model teater wayang tersebut disinergikan ke dalam wujud garapan wayang yang bernuansa inovatif, dengan tema cerita yang diambil dari lakon Tantri yang berjudul Wrémada.

Konsep imajinasi digunakan karena penggarap bercerita mengenai dimensi lain yaitu dimensi imajinasi atau dunia khayalan. Imajinasi yang merupakan daya untuk membentuk gambaran (imaji) atau konsep-konsep mental yang tidak secara langsung didapatkan dari sensasi (penginderaan). Imajinasi dalam pemahamannya mengandaikan pula adanya citra atau gambaran yang merupakan unsur sangat penting di dalamnya, maka dari itu proses mengimajinasikan itu selalu merupakan proses membentuk gambaran tertentu yang terjadi secara mental.

Garapan ini merupakan salah satu komponen widya dan filsafat untuk meningkatkan pem- bangunan karakter dan jati diri bangsa, karena mengangkat tema tentang pengungkapan arogansi kepemimpinan di dalam mengambil keputusan maupun bertindak yang selalu memaksa kehendak sendiri, dan bersifat angkuh dalam mengemban jabatannya. Harapan penggarap, cerita tersebut menjadi cermin bagi masyarakat ketika menjadi pemimpin agar bersikap bijaksana dan berpedoman pada catur pariksa atau disebut juga dengan nama catur nayasandhi yaitu sama, beda, dana, dan danda. Pedoman tersebut mampu memberikan arahan yang bijaksana bagi seorang pemimpin, baik dalam bersikap maupun bertindak dalam melaksanakan tugasnya. Fenomena inilah yang menjadi ide yang ingin penggarap wujudkan, karena zaman sekarang banyak kasus tentang sosok pemimpin yang semestinya mengayomi masyarakatnya dengan benar, justru terjerat beberapa kasus yang merugikan masyarakat bahkan negaranya sendiri.

\section{Kepustakaan}

\section{a. Acuan}

Catra, I Nyoman. 2013. ”Wayang Lemah: Fungsi, Makna dan Kontekstualnya dalam Upacara Agama Hindu”. Makalah Semiloka Wayang Lemah. Mangupura: Dinas Kebudayaan Kabupaten Badung, Himpunan Seniman Kabupaten Badung.

Endraswara, Suwardi. 2011. Metode Pembelajaran Drama: Apresiasi, Ekspresi, dan Pengkajian. Yogyakarta: CAPS.

Moeliono, Anton M. 1998. Kamus Besar Bahasa Indonesia. Jakarta: Balai Pustaka Bahasa.

Ngurah, I Gusti Made. 1993. Buku Pendidikan Agama Hindu Untuk Perguruan Tinggi. Surabaya: Paramita.

Sugono, Dendy. 2008. Kamus Besar Bahasa Indonesia Pusat Bahasa. Jakarta: PT Gramedia. Suteja, I Kt. 2012.Catur Asrama: Pendakian Spiritual Masyarakat Bali Dalam Sebuah Karya Tari. Disertasi. Institut Seni Indonesia Yogyakarta.

Taro, I Made. 2009. Kisah-Kisah Tantri. Denpasar: Sanggar Kukuruyuk.

Tedjoworo, H. 2001. Imaji dan Imajinasi. Yogyakarta: Kanisius.

Wahyudi, Aris. 2014. "Sambung-rapet dan Gregetsahut dalam Dramaturgi Wayang" dalam 
Wayang Nusantara: Journal of Puppetry. Vol. 1 No. 1. September 2014, (1 -12).

Zoetmulder, P.J. 1995. Kamus Jawa Kuna Indonesia. Yogyakarta: PT. Gramedia Pusaka Utama.

\section{b. Audio-Visual}

Wayan Wija. 2008. Wayang Kulit Tantri Sang Aji
Darma Kepastu. VCD. Bali Record.

Yayasan Gagat Enjang, 2009. Wayang Kulit Binatang Kisah Si Bojog. VCD.

I Ketut Kodi. 2010. Wayang Betel Gua Gala-gala. VCD. Koleksi Pribadi

I Ketut Sudiana. 2010. Grenyem Leak. Video. Koleksi Pribadi. 